\title{
Perbandingan Kualitas Tanah Di Pantai Alasdowo Kabupaten Pati Dengan Pantai Mangunharjo Kota Semarang Sebagai Media Pertumbuhan Mangrove Rhizophora Sp.
}

\author{
${ }^{1}$ Ahmad Shofanduri, ${ }^{2}$ Lianah, ${ }^{3}$ Anif Rizqianti Hariz \\ ${ }^{123}$ ProgramStudi Pendidikan Biologi, Fakultas Sains dan Teknologi, UIN Walisongo Semarang \\ ${ }^{1}$ shofanduri@yahoo.com, ${ }^{2}$ lianah@walisongo.ac.id , ${ }^{3}$ anifrizqianti@walisongo.ac.id
}

\begin{abstract}
ABSTRAK
Pantai Alasdowo dan Pantai Mangunharjo merupakan kawasan ekosistem mangrove yang berada di kawasan pesisir pulau Jawa. Pada kedua lokasi tersebut tumbuh berbagai macam jenis mangrove, akan tetapi di kawasan Pantai Mangunharjo memiliki tingkat pertumbuhan mangrove yang lebih baik dibandingkan dengan pertumbuhan mangrove di Pantai Alasdowo. Perbedaan tingkat pertumbuhan bisa disebabkan oleh berbagai faktor. Penelitian ini bertujuan untuk mengetahui kualitas tanah di Pantai Alasdowo dan Pantai Mangunharjo. Hasil penelitian menunjukkan sifat fisik tanah yang meliputi tekstur dan warna tanah, serta sifat kimia tanah meliputi $\mathrm{pH}$ dan salinitas tanah pada kedua pantai berbeda tetapi masih dalam batas toleransi pertumbuhan Rhizoporasp. Perbedaan pertumbuhan mangrove pada kedua pantai tersebut dapat dipengaruhi oleh faktor lain yang dalam penelitian ini tidak dikaji, misalnya aktivitas manusia di sekitar lokasi penelitian.
\end{abstract}

Kata Kunci: kualitas tanah, Rhizophorasp., sifat fisik tanah, sifat kimia tanah

\begin{abstract}
Alasdowo Beach and Mangunharjo Beach are mangrove ecosystems located in the coastal area of Java. In both locations, various types of mangroves grew, but in the Mangunharjo Beach area there was a better level of mangrove growth compared to the growth of mangroves on Alasdowo Beach. Differences in growth rates can be caused by various factors. This study aims to determine the quality of land on Alasdowo Beach and Mangunharjo Beach. The results showed the physical properties of the soil including the texture and color of the soil, as well as the chemical properties of the soil including $\mathrm{pH}$ and soil salinity on the two different beaches but still within the tolerance tolerance of growth of Rhizopora sp. The difference in mangrove growth on both beaches can be influenced by
\end{abstract}


other factors which in this study were not examined, for example human activities around the study site.

Keywords: soil quality, Rhizophora sp., Soil physical properties, soil chemical properties

\section{PENDAHULUAN}

Hutan mangrove merupakan tipe hutan yang khas terdapat di sepanjang pantai atau muara sungai, yang telah menyesuaikan diri dengan terpaan ombak yang kuat dengan tingkat salinitas yang tinggi serta tanah yang senantiasa digenangi air. Hutan pantai tersebut tumbuh di daerah tropis maupun subtropis. Istilah mangrove digunakan masyarakat tumbuh-tumbuhan (hidrosere communities) dari beberapa jenis tumbuhan pantai dan hutan itu disebut hutan pantai (coastal woodland) atau hutan pasang surut (tidal forest) (Fachrul, 2007).Ekosistem hutan mangrove merupakan salah satu ekosistem yang memiliki produktivitas tinggi dibandingkan ekosistem lain dengan dekomposisi bahan organik yang tinggi, dan menjadikannya sebagai mata rantai ekologis yang sangat penting bagi kehidupan mahluk hidup yang berada di perairan sekitarnya. Materi organik menjadikan hutan mangrove sebagai tempat sumber makanan dan tempat kehidupan berbagai biota seperti ikan, udang, dan kepiting. Berbagai kelompok mollusca ekonomis juga sering ditemukan di perairan pantai mangrove seperti cacing laut (polychaeta).

Hutan mangrove merupakan sumber daya alam yang memiliki beberapa sifat khusus di antaranya letak hutan mangrove yang sangat spesifik, peranan ekologisnya yang khas, potensi yang bernilai ekonomis tinggi. Mangrove juga merupakan ekosistem dengan fungsi yang unik dalam lingkungan hidup karena adanya pengaruh laut dan daratan. Kawasan mangrove terjadi interaksi kompleks antara sifat fisika dan biologi, karena sifat fisiknya mangrove mampu berperan sebagai penahan ombak serta penahan intrusi dan abrasi air laut.

Ciri khas hutan mangrove yakni bentuk-bentuk perakaran yang menjangkar dan bersifat pneumatophore. Pneumotophore (akar nafas) adalah akar yang tumbuh dan berkembang dengan fungsi sebagai pembantu pernafasan tanaman. Perakaran ini menjadikan proses penangkapan partikel dari debu di 
tegakan Rhizophora sp. berjalan secara sempurna. Pembentukan sedimen dipengaruhi oleh adanya pasang surut yang membawa partikel-partikel yang diendapkan pada saat surut (Ningsih, 2008).

Pada umumnya terdapat empat jenis tumbuhan yang dijumpai di hutan mangrove, yaitu pohon Api-api (Avicennia), Bakau (Rhizopora), Tanjang (Bruguiera), dan Pedada (Sonneratia) (Fachrul, 2007). Setiap jenis tumbuhan mangrove memiliki kemampuan adaptasi yang berbeda-beda terhadap kondisi lingkungan seperti kondisi tanah, salinitas, temperatur, curah hujan dan pasang surut. Hal ini menyebabkan terjadinya struktur dan komposisi tumbuhan mangrove dengan batas-batas yang khas, mulai dari zona yang dekat dengan daratan sampai dengan zona yang dekat dengan lautan, serta menyebabkan terjadinya perbedaan struktur tumbuhan mangrove dari satu daerah dengan daerah lainnya.

Komponen yang mempengaruhi pertumbuhan dan perkembangan tumbuhan salah satunya adalah tanah. Tanah merupakan salah satu komponen sistem produksi tanaman yang sangat penting untuk diperhatikan dan tanah sebagai sumber daya lahan utama untuk produksi pangan. Berkaitan dengan itu, tanah juga sebagai tempat hidup semua organisme mulai dari organisme tingkat rendah (mikrobia) sampai organisme tingkat tinggi (tanaman). Sebagai tempat hidup organisme, tanah mempunyai peranan utama untuk menopang salah satu faktor penting pertumbuhan dan perkembangan tanaman yaitu pemasok unsur hara atau makanan. Dengan demikian tanah yang subur artinya tanah yang kaya unsur hara yang akan memberikan produksi tanaman yang tinggi. Unsur hara yang ada di dalam tanah akan semakin berkurang atau bahkan habis. Hal ini bisa diakibatkan oleh penyerapan secara terus menerus oleh tanaman ataupun hilang terbawa hasil panen atau hilang bersama air limpasan akibat curah hujan yang tinggi.

Tujuan dari penelitian ini adalah untuk mengetahui kualitas tanah di Pantai Alasdowo Kabupaten Pati dan di Pantai Mangunharjo Kota Semarang sebagai media pertumbuhan Rhizophora sp. Berdasarkan informasi yang diperoleh dari masyarakat Desa Alasdowo, Kecamatan Dukuhseti, Kabupaten Pati, bahwa di pantai Alasdowo, Rhizophora sp. yang ditanam di pantai tersebut tingkat 
pertumbuhannya kurang baik. Peneliti mencoba mengetahui sebab permasalahan tersebut dari segi ekologi, khususnya pada kondisi tanah. Selanjutnya, kualitas tanah mangrove di Desa Alasdowo ini dibandingkan dengan kondisi tanah di Pantai Mangunharjo, Kecamatan Tugu, Kota Semarang. Pantai Mangunharjo dipilih sebagai pembanding karena berdasarkan hasil pra-riset diperoleh bahwa Rhizophora sp. yang ada di Pantai Mangunharjo dapat tumbuh subur.

\section{METODE PENELITIAN}

Penelitian ini merupakan penelitian lapangan. Metode yang digunakan adalah metode deskriptif eksploratif. Penelitian ini dilakukan di kawasan pesisir Desa Alasdowo Kecamatan Dukuhseti Kabupaten Pati dan kawasan pesisir Desa Mangunharjo Kecamatan Tugurejo Kota Semarang. Penelitian ini dilaksanakan pada bulan Mei-Juni 2017.

Fokus dari penelitian ini adalah analisis kualitas tanah tempat Rhizophora sp. hidup di Pantai Alasdowo dan Pantai Mangunharjo. Parameter tanah yang diambilyaitu tekstur, warna, $\mathrm{pH}$, dan salinitas tanah. Sampel dalam penelitian ini adalah tanah pesisir Pantai Alasdowo dan Mangunharjo. Pengambilan sampel tanah pada kisaran kedalaman tanah 15-35 cm (top soil) atau lebih, pada lapisan ini terkandung humus atau bahan-bahan organik serta zat-zat hara mineral yang sangat diperlukan bagi tanaman (Kartasapoetra, 2010). Sampel tanah diambil dari beberapa titik pada lokasi pengambilan sampel yang telah ditentukan.

Bahan dan alat dalam penelitian ini sebagai berikut.

1. Bahan: tanah tempat tumbuh mangrove di Pantai Alasdowo dan Pantai Mangunharjo.

2. Alat: cangkul, meteran, raffia, kamera, botol, coolerbox, soil tester.

Stasiun pengamatan ditetapkan sebanyak 3 stasiun dengan area sepanjang transek garis yang dibentangkan dari arah laut menuju daratan. Setiap stasiun ditentukan 2 plot transek. Masing-masing plot transek berjarak 20 meter, sedangkan jarak antar stasiun sekitar 10 meter. 


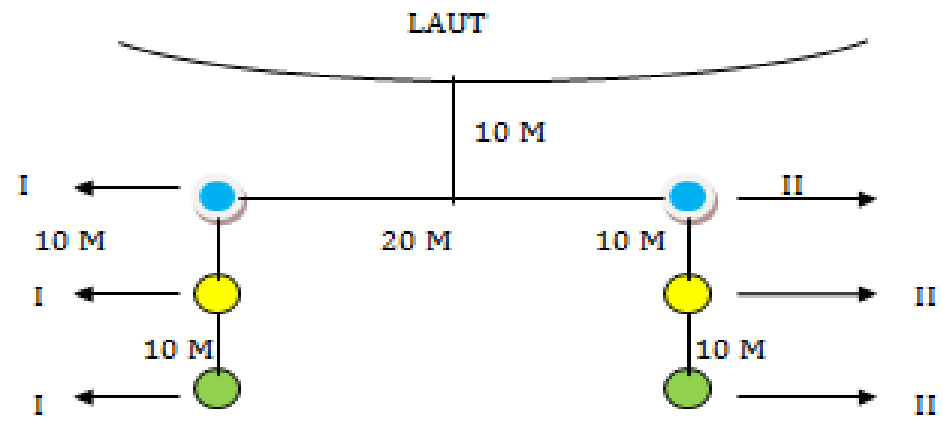

Gambar 1. Skematik penempatan transek pengukuran sampel tanah di lokasi pengamatan

Keterangan:

- : Stasiun 1 (transek I dan II)

: Stasiun 2 (transek I dan II)

: Stasiun 3 (transek I dan II)

\section{PEMBAHASAN}

1. Sifat Fisik Tanah

a. Tekstur tanah

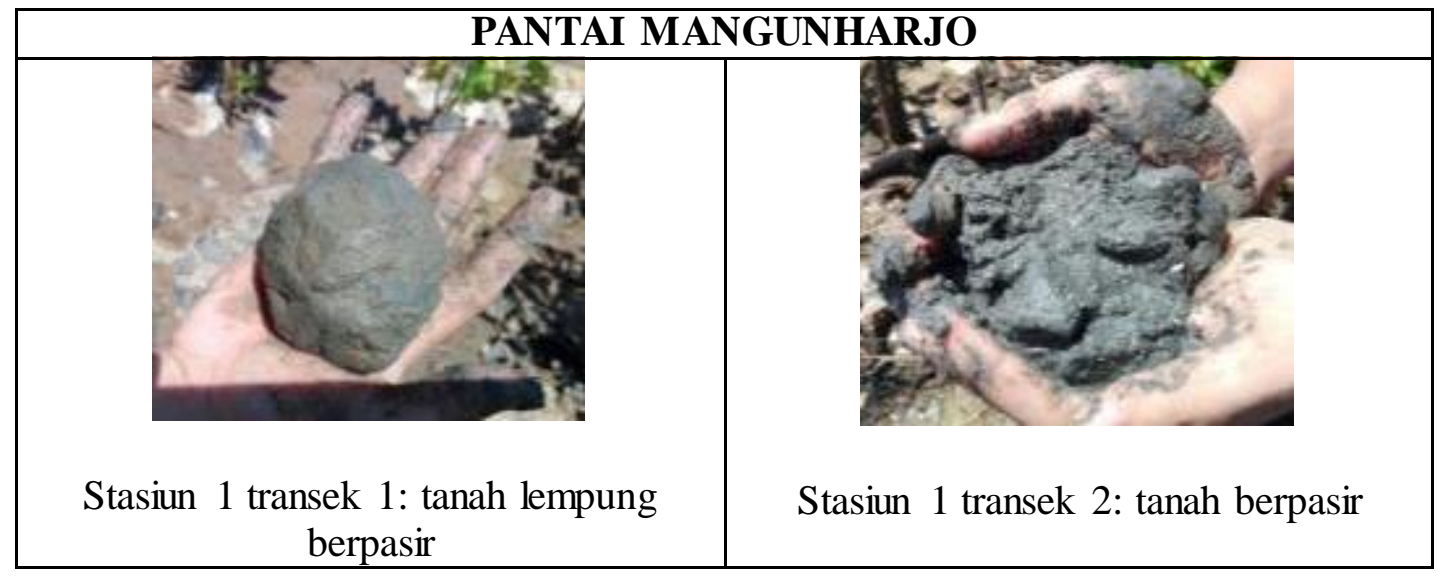




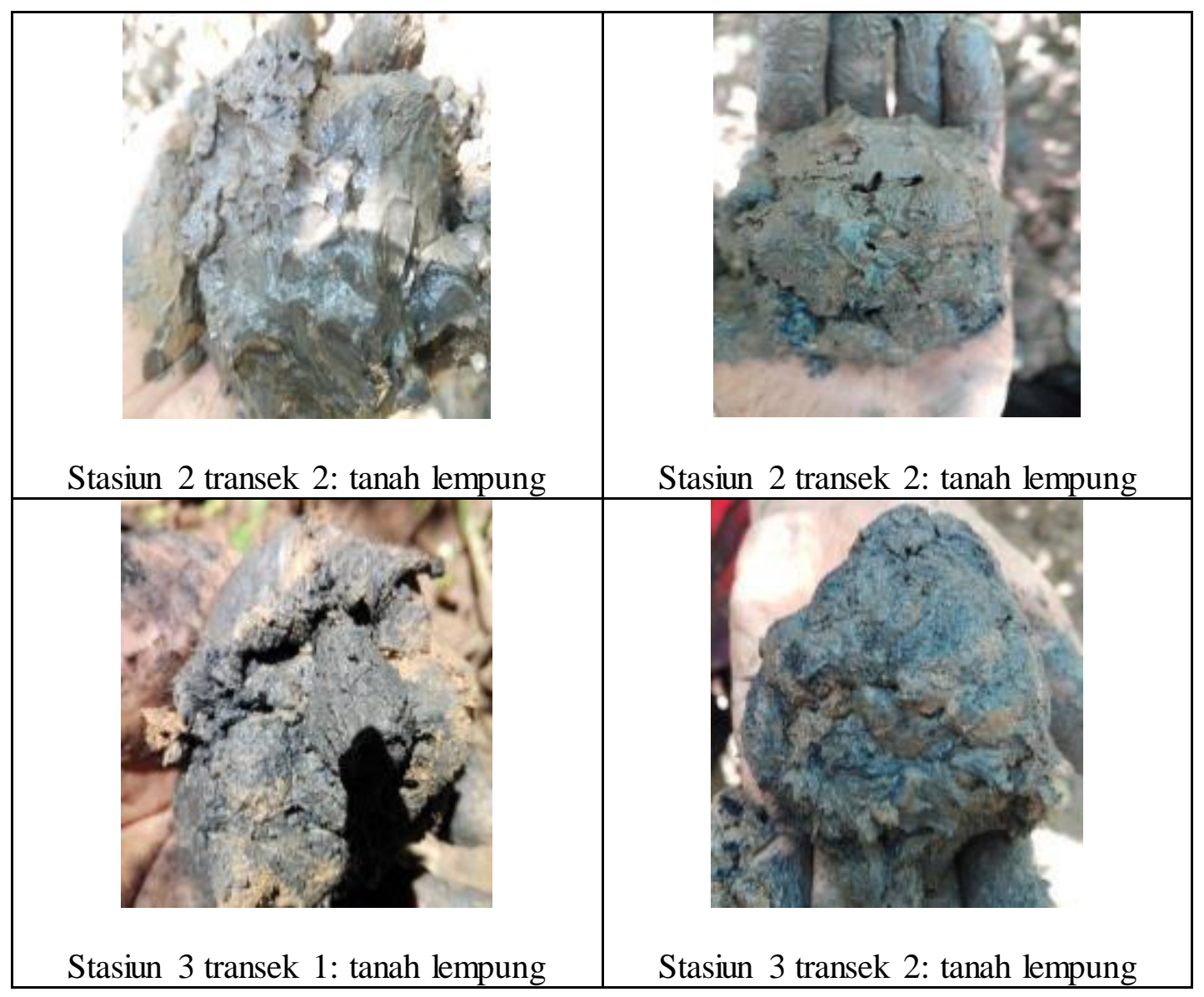

\begin{tabular}{|l|l|}
\hline \multicolumn{2}{|c|}{ PANTAI MANGUNHARJO } \\
\hline (2) \\
$\begin{array}{c}\text { Stasiun 1 transek 1: tanah lempung } \\
\text { berpasir }\end{array}$ & Stasiun 1 transek 2: tanah berpasir \\
\hline
\end{tabular}




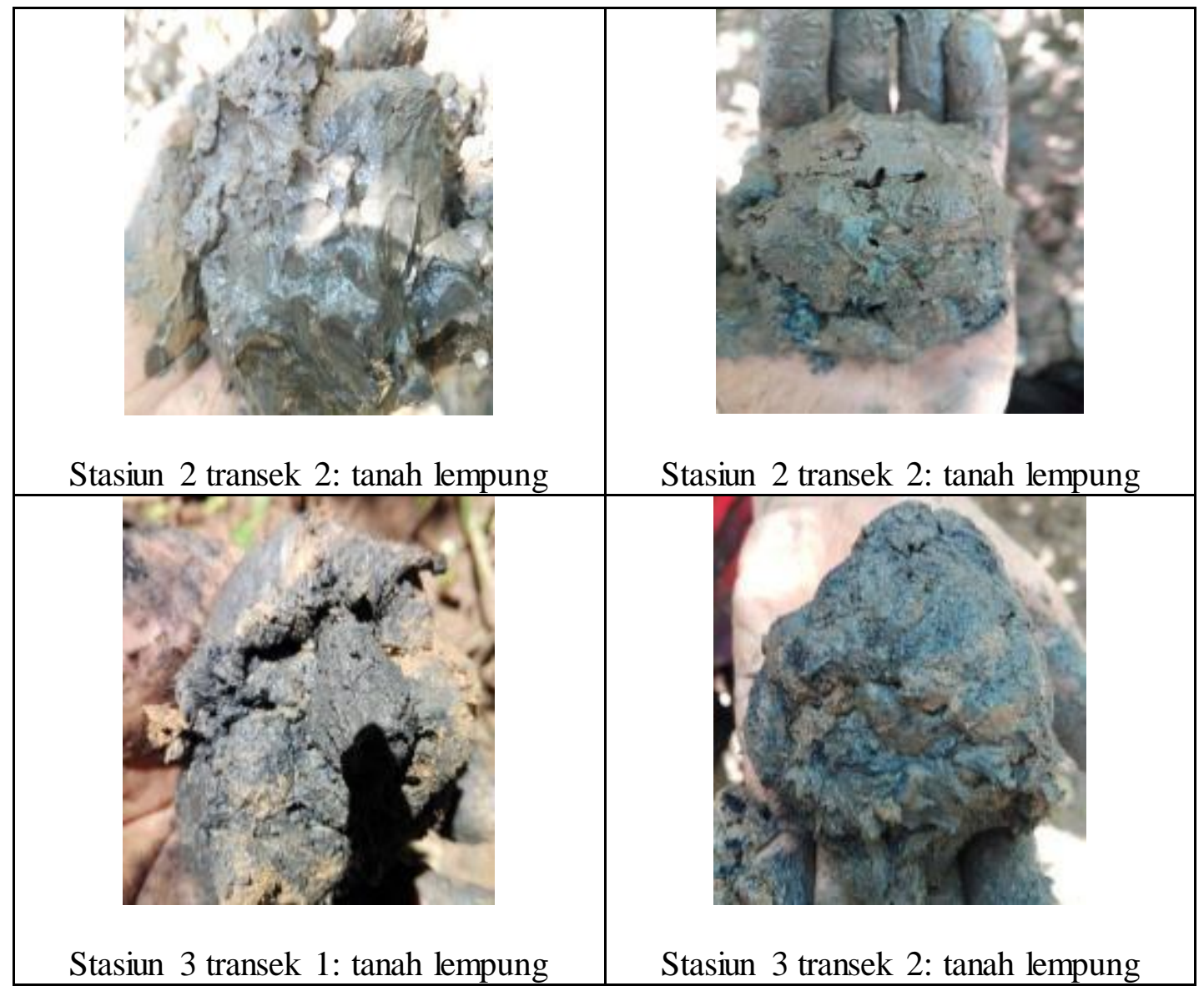

Gambar 2. Tekstur tanah Pantai Alasdowo dan Pantai Mangunharjo

Alik, dkk (2012) menyatakan bahwa jenis Rhizophora sp. umumnya mampu hidup pada substrat berlumpur dan berpasir. Dari hasil penelitian, didapatkan bahwa tanah pada kedua pantai tersebut dapat mendukung pertumbuhan Rhizophora sp. Di Pantai Alasdowo, pada jarak $\pm 20-30 \mathrm{~m}$ dari arah laut jenis Rhizophora sp. yang memungkinkan untuk tumbuh adalah dari jenis Rhizophora mucronata dan Rhizophora stylosa. Pada jarak $\pm 40 \mathrm{~m}$ jenis Rhizophora yang bisa tumbuh dengan baik adalah Rhizophora apiculata dan Rhizophora mucronata. Sedangkan di Pantai Mangunharjo, Rhizophora mucronata dan Rhizophora stylosa bisa tumbuh pada jarak $\pm 20 \mathrm{~m}$ dari arah laut. Sedangkan pada jarak \pm 30-40 $\mathrm{m}$ dari arah laut yang memungkinkan tumbuh adalah Rhizophora apiculata dan Rhizophora mucronata.

Sosia, dkk. (2014) menyatakan, bahwa Rhizophora apiculata tumbuh pada tanah berlumpur, halus, dalam dan tergenang pada saat pasang normal, tidak 
menyukai substrat yang lebih keras yang bercampur pasir. Sedangkan Rhizophora mucronata tumbuh di areal yang sama dengan Rhizophora apiculata tetapi lebih toleran terhadap substrat yang lebih keras dan pasir. Pertumbuhan optimal pada areal yang tergenang dalam serta tanah yang kaya akan humus. Aksornkoae (1993) dalam Alik, dkk (2012) menyatakan bahwa Rhizophora mucronata akan tumbuh dengan baik pada tipe substrat lumpur yang relatif tebal, $\mathrm{pH}$ tanah berkisar 6,2-6,6, serta berkembang dengan baik pada kisaran salinitas 10-30 \% Adapun Rhizophora stylosa memiliki habitat dari tanah yang berlumpur, pasir, sampai pecahan batu atau karang. Bakau ini juga ditemukan mulai dari tepi pantai hingga daratan yang mengering (Tjandra, 2011).

Flora mangrove dalam beradaptasi dengan habitatnya yang berupa substrat lumpur dan selalu tergenang dengan membentuk akar-akar khusus untuk dapat tumbuh dengan kuat dan membantu mendapatkan oksigen. Rhizophora sp. menggunakan akar tunjang dan akar gantung untuk beradaptasi pada substrat yang berupa lumpur dan selalu tergenang. Akar tunjang keluar dari batang dan tumbuh ke dalam substrat sedangkan akar gantung tumbuh dari batang tetapi biasanya tidak mencapai substrat. Perbedaan tekstur tanah pada lokasi penelitian tentunya berpengaruh dalam kesuburan tanah, karena tekstur tanah berhubungan dengan pertukaran dan penyanggaan (penahanan) ion-ion hara tanaman dalam tanah. Substrat berpasir memiliki kemampuan menyerap ion dan air sangat rendah, hal ini tentunya berpengaruh pada kemampuan tanah menyimpan cadangan air atau unsur hara di dalam tanah. Jika mangrove kekurangan air dan unsur hara maka tanaman layu/kering bahkan mati. Berbeda dengan substrat lempung atau liat yang memiliki tekstur lebih halus sehingga memiliki diameter yang lebih kecil dari pada pasir. Hal ini yang menjadikan substrat liat atau lempung memiliki kemampuan yang baik dalam menahan air dan unsur hara yang kemudian digunakan oleh mangrove untuk proses metabolisme.

\section{b. Warna tanah}

Warna tanah ditentukan dengan cara membandingkan warna sampel tanah yang terlihat dengan warna baku yang ada pada aplikasi Soil Color Chart (dapat 
diunduh pada aplikasi Google Play yang diunggah oleh Innocenti pada tahun 2012).

Tabel 1. Perbandingan Warna Tanah Pantai Alasdowo dan Pantai Mangunharjo

\begin{tabular}{llllllll}
\hline No & Nama & Stasiun I & \multicolumn{3}{c}{ Stasiun II } & Stasiun III \\
- & Data & Transek I & $\begin{array}{l}\text { Transe } \\
\text { k II }\end{array}$ & $\begin{array}{l}\text { Transe } \\
\text { k I }\end{array}$ & Transek II & Transek I & Transek II \\
\cline { 3 - 8 } & & & & & & \\
1. & Alasdowo & Hitam & Hitam & Hitam & Hitam & Abu-abu & Abu-abu \\
2. & Mangunharj & Hitam & Hitam & Abu- & Hitam & Hitam & Hitam \\
& o & kecoklata & & abu & kecoklata & kecoklata & kecoklata \\
& & $n$ & & & $n$ & $n$ & $n$ \\
\hline
\end{tabular}

Hasil pengamatan warna tanah pada masing-masing transek pada 2 lokasi dapat ditentukan bahwa tanah Pantai Alasdowo berwarna abu-abu - hitam dengan gradasi warna yang berbeda tetapi hampir sama pada masing-masing transek, foto warna tanah dapat dilihat pada Gambar 2. Pantai Mangunharjo pada stasiun 1 transek 1 dan 2 memiliki warna hitam dengan gradasi warna yang berbeda juga transek 2 memiliki gradasi warna yang lebih gelap dari transek 1. Pada stasiun 2 transek 1 tanah memiliki warna abu-abu dan stasiun 1 transek 1, stasiun 3 transek 1 dan 2 memiliki perpaduan warna antara hitam dan coklat yang tidak menyatu.

Perbedaan warna pada masing-masing lokasi penelitian menurut Notodarmojo (2005), dipengaruhi oleh kandungan dan komposisi mineral serta posisi topografi tanah. Tanah dengan kandungan organik yang tinggi akan berwarna kegelapan dengan nuansa coklat atau hitam, dan umumnya relatif subur. Tanah yang berwarna keputihan biasanya memiliki tingkat kesuburan yang rendah. Tanah yang telah diamati memiliki warna yang tidak murni artinya pada satu lapisan ada warna gelap coklat kekuningan atau bahkan karena campuran dari warna-warna tersebut muncul warna baru. Hanafiah (2014) mengatakan bahwa kebanyakan tanah memiliki warna tanah yang tidak murni karena merupakan campuran dari beberapa warna dan menurut Notodarmojo (2005) bahwa sering ditemui di lapangan suatu horizon tanah mempunyai warna yang dominan tetapi juga dijumpai pada suatu horizon mempunyai beberapa warna atau mungkin juga 
memiliki spot warna yang berbeda, seperti bintik-bintik (mottled). Hal ini disebabkan karena sistem drainase dan aerasi yang kurang merata.

\section{Sifat Kimia Tanah}

a. pH Tanah

Pengukuran $\mathrm{pH}$ tanah pada kedua lokasi didapatkan hasil yang tersaji pada Tabel 2.

Tabel 2. Perbandingan pH Tanah Pantai Alasdowo dan Pantai Mangunharjo.

\begin{tabular}{|c|c|c|c|c|c|c|c|}
\hline$\overline{\text { No. }}$ & Nama & Stasiun I & & Stasiun II & & Stasiun II & \\
\hline & Data & Transek I & Transek II & Transek I & Transek II & Transek I & Transek II \\
\hline 1. & Alasdowo & $\overline{5,2}$ & 5,0 & 6,2 & 6,4 & 6,2 & 6,4 \\
\hline 2. & Mangunharjo & 5,8 & 5,4 & 6,4 & 6,2 & 6,4 & 6,4 \\
\hline
\end{tabular}

Hasil pengukuran pH di lokasi penelitian, Pantai Alasdowo memiliki kisaran pH 5-6,4 dan Pantai Mangunharjo memiliki kisaran pH 5,4-6,4. Hasil pengukuran kedua lokasi tersebut kisaran nilai $\mathrm{pH}$ masih dalam batas toleransi mangrove, karena secara umum mangrove dapat hidup pada $\mathrm{pH}$ berkisar 5-8,5 (Widyastuti dan Wahyu, 1998 dalam Pariyono, 2006). Selain itu, Aksornkoae (1993) dalam Alik, dkk (2012) juga menyatakan bahwa Rhizophora mucronata akan tumbuh dengan baik pada kisaran $\mathrm{pH}$ 6,2-6,6.

Reaksi tanah menunjukkan sifat kemasaman atau alkalinitas tanah yang dinyatakan dengan nilai $\mathrm{pH}$. Nilai $\mathrm{pH}$ menunjukkan banyaknya konsentrasi ion hidrogen $(\mathrm{H}+)$ di dalam tanah. Semakin tinggi ion $\mathrm{H}+$ di dalam tanah, maka semakin masam tanah tersebut. Mikroorganisme memiliki peranan penting di dalam tanah, karena mereka yang berperan dalam mengubah atau melakukan transformasi zat organik sisa tumbuhan atau hewan menjadi nutrien yang dibutuhkan oleh tumbuhan. Aktivitas metabolisme mikroorganisme dipengaruhi oleh $\mathrm{pH}$. Selain berpengaruh pada reaksi abiotik, $\mathrm{pH}$ juga berpengaruh pada reaksi biotik. Parameter $\mathrm{pH}$ akan mempengaruhi kemampuan fungsi-fungsi sel, seperti transport melalui membran sel, keseimbangan reaksi yang terkatalis oleh enzim. 
Hampir semua mikroorganisme akan tumbuh baik pada pada $\mathrm{pH}$ mendekati normal (sekitar 7) (Notodarmojo, 2005).

\section{b. Salinitas tanah}

Hasil analisis parameter salinitas tanah di lokasi penelitian dapat dilihat pada Tabel 3.

Tabel 3.Hasil Pengukuran Salinitas Tanah di Pantai Alasdowo dan Pantai Mangunharjo

\begin{tabular}{|c|c|c|c|c|c|c|c|}
\hline No. & Nama & Stasiun I & & Stasiun II & & Stasiun II & \\
\hline & Data & Transek I & Transek II & Transek I & Transek II & Transek I & Transek II \\
\hline 1. & Alasdowo & 11,45 & 11,78 & 12,40 & 13,02 & 12,33 & 12,41 \\
\hline 2. & Mangunharjo & 12,34 & 10,90 & 13,24 & 14,02 & 12,67 & 11,28 \\
\hline
\end{tabular}

Tabel hasil pengukuran salinitas menunjukkan bahwa kualitas tanah di lokasi penelitian di Pantai Mangunharjo dan Pantai Alasdowo memiliki kualitas tanah yang baik sebagai tempat tumbuhnya mangrove khususnya jenis Rhizophora sp.. Salinitas tanah di Pantai Mangunharjo berkisar antara 10,9014,02. Sedangkan salinitas tanah di Pantai Alasdowo berkisar antara 11,45-13,02. Nilai salinitas ini masih sangat cocok untuk pertumbuhan hampir semua mangrove khususnya Rhizophora sp.. Bengen dan Datton (2004) dalam Alik (2012) menyatakan bahwa Rhizophora sp. berkembang baik pada kisaran salinitas 10-30 \% $\%$. Pada penelitian Hutahaean (1999), untuk melihat pertumbuhan jenis Rhizophora mucronata yang baik diperoleh pada salinitas 7,5-15.

Tumbuhan mangrove dapat berkembang pada kondisi lingkungan yang ekstrim, akan tetapi setiap tumbuhan mangrove mempunyai kemampuan yang berbeda untuk mempertahankan diri terhadap kondisi lingkungannya. Pada lokasi penelitian memiliki waktu pasang surut yang berbeda. Berdasarkan data yang diperoleh peneliti bahwa di Pantai Mangunharjo terjadi pasang air laut hampir setiap hari yang terjadi pada siang hari dan surut pada sore menjelang malam hari. Pantai Alasdowo juga terjadi air pasang hampir setiap hari, tetapi dalam jangka 
waktu yang lebih lama yaitu mulai pagi hari dan akan surut pada tengah malam hari. Tinggi dan waktu penggenangan air pasang yang cukup lama inilah yang akan menentukan salinitas tanah. Menurut Notodarmojo (2005), kadar garam terlarut akan mempengaruhi tekanan osmotis dari larutan air tanah atau kelembaban yang ada. Hal ini akan mempengaruhi mikroorganisme yang ada dalam tanah. Seperti diketahui bahwa mikroorganisme mempunyai membran yang sangat berperan penting dalam metabolismenya. Berubahnya tekanan osmotis, maka transport substrat atau nutrisi yang melalui sel membran akan terpengaruh juga. Tekanan osmosis dalam sel harus lebih tinggi bila dibandingkan dengan larutan tanah di sekitarnya sehingga aliran akan masuk ke dalam sel. Apabila tekanan osmosis dalam sel lebih rendah dibandingkan dengan larutan tanah di sekitarnya maka aliran yang berisi substrat atau nutrisi tidak akan masuk ke dalam sel. Kadar garam juga berpengaruh terhadap mangrove. Kadar garam yang sangat tinggi dapat menimbulkan tekanan osmotik yang negatif. Akibatnya, tajuk mangrove semakin jauh dari tepian, secara umum menjadi kerdil dan berkurang komposisi jenisnya.

Syah (2011) menyatakan bahwa Rhizophora sp memiliki beberapa cara untuk beradaptasi terhadap kandungan garam antara lain:

1) Sekresi garam (Salt Extrusion / Salt Secretion), yaitu menyerap air dengan salinitas tinggi kemudian mensekresikan garam dengan kelenjar garam yang terdapat pada daun.

2) Mencegah masuknya garam (Salt Exclusion), yaitu menyerap air tetapi mencegah masuknya garam melalui saringan (ultra filter) yang terdapat pada akar.

3) Akumulasi garam (Salt Accumulation). Mangrove seringkali menyimpan $\mathrm{Na}$ dan $\mathrm{Cl}$ pada bagian kulit kayu, akar dan daun yang lebih tua. Daun penyimpan garam ini umumnya sukulen dan pengguguran daun sukulen ini diperkirakan merupakan mekanisme mengeluarkan kelebihan garam yang dapat menghambat pertumbuhan dan pembentukan buah. 


\section{SIMPULAN}

Hasil penelitian sifat fisik dengan parameter tekstur dan warna tanah dan sifat kimia tanah dengan parameter $\mathrm{pH}$ dan salinitas tanah pada kedua lokasi penelitian ada beberapa perbedan akan tetapi perbedaan tersebut masih dalam batas toleransi faktor pertumbuhan Rhizophora sp. Perbedaan pertumbuhan Rhizophora sp. pada kedua lokasi tersebut dapat disebabkan oleh faktor fisikakimia lainnya yang tidak diteliti dalam penelitian ini. Menurut Supriharyono (2009) ada faktor yang lebih penting lagi dalam menentukan kehidupan dan kelestarian ekosistem mangrove selain faktor fisik-kimia yaitu aktivitas manusia, yang dalam penelitian ini tidak dikaji.

\section{DAFTAR PUSTAKA}

Alik, T.S.D., M.R. Umar, dan D. Priosambodo. (2012). Analisis Vegetasi Mangrove di Pesisir Pantai Mara Bombang Kab. Pinrang. Makasar: Universitas Hasanudin Press.

Fachrul, Melati Ferianita. (2007). Metode Sampling Bioekologi. Jakarta: Bumi Akasara.

Hanafiah, K.A. (2014). Dasar-dasar Ilmu Tanah. Jakarta: Rajawali Pers.

Hutahaean, E.E., C. Kusmana, H.R. Dewi. (1999). Studi Kemampuan Tumbuh Anakan Mangrove Jenis Rhizophora mucronata, Bruguiera gimnorrhiza, dan Avicennia marina Pada Berbagai Tingkat Salinitas. Jurnal Manajemen Hutan Tropika. 5(1): 77-85.

Kartasapoetra, A.G. (2010). Teknologi Konservasi Tanah dan Air. Jakarta: Rineka Cipta.

Ningsih, S.S. (2008). Inventarisasi Hutan Mangrove Sebagai Bagian Dari Pengelolaan Wilayah Pesisir Kabupaten Deli Serdang. Tesis. Pascasarjana Universitas Sumatra Utara.

Notodarmojo, S. (2005). Pencemaran Tanah dan Air Tanah. Bandung: Penerbit ITB.

Pariyono. (2006). Kajian Potensi Kawasan Mangrove dalam Kaitannya dengan Pengelolaan Wilayah Pantai di Desa Panggung, Bulakbaru, Tanggultlare, 
Kabupaten Jepara. Tesis Fakultas Perikanan dan Kelautan, Universitas Diponegoro.

Sosia, Y.P., R. Tyagita, N. Mega. (2014). Mangrove Siak dan Kepulauan Meranti. Jakarta: Energi Mega Persada.

Syah, C. (2011). Pertumbuhan tanaman bakau (Rhizophora mucronata) pada lahan restorasi mangrove di hutan lindung Angke Kapuk Provinsi DKI Jakarta. Tesis Program Pascasarjana, IPB.

Tjandra, E. dan Siagian, Y.R. (2011). Mengenal Hutan Mangrove. Bogor: Cita Insan Madani. 